\title{
Self-passivating tungsten alloys of the system W-Cr-Y for high temperature applications
}

\author{
A. Calvo ${ }^{\mathrm{a}}, \mathrm{K}$. Schlüter $^{\mathrm{b}, \mathrm{c}}, \mathrm{E}$. Tejado ${ }^{\mathrm{e}}$, G. Pintsuk ${ }^{\mathrm{d}}$, \\ N. Ordás ${ }^{\mathrm{a}}$, I. Iturriza ${ }^{\mathrm{a}}$, R. Neu ${ }^{\mathrm{b}, \mathrm{c}}$, J.Y. Pastor ${ }^{\mathrm{e}}$, C. García-Rosales ${ }^{\mathrm{a},{ }^{*}}$
}

${ }^{a}$ Ceit-IK4 and Tecnun (University of Navarra), Paseo de Manuel Lardizabal 15, E-20018 San Sebastian, Spain

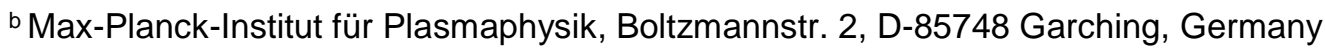

${ }^{c}$ Technische Universität München, Boltzmannstr. 15, D-85748 Garching, Germany

${ }^{d}$ Forschungszentrum Jülich GmbH, Institut für Energie- und Klimaforschung - Plasmaphysik, D-52425 Jülich, Germany

e Departamento de Ciencia de Materiales-CIME, Universidad Politécnica de Madrid, c/ Profesor Aranguren 3, E28040-Madrid, Spain

\begin{abstract}
\footnotetext{
${ }^{*}$ Corresponding author: Carmen García-Rosales Ceit-IK4 Technology Center and Tecnun (University of Navarra) po de Manuel Lardizabal, 15 20018 San Sebastian, Spain. Tel.: +(34) 943212800 E-mail address: cgrosales@ceit.es
}

Self-passivating tungsten based alloys for the first wall armor of future fusion reactors are expected to provide a major safety advantage compared to pure tungsten in case of a loss-of-coolant accident with simultaneous air ingress, due to the formation of a stable protective scale at high temperatures in presence of oxygen which prevents the formation of volatile and radioactive $\mathrm{WO}_{3}$. This work analyses the oxidation and thermo-shock resistance of W-Cr-Y alloys obtained by mechanical alloying followed by HIPing. Alloys with different $\mathrm{Cr}$ and $\mathrm{Y}$ contents are produced in fully dense form with nanocrystalline or ultrafinegrained microstructure and a dispersion of Y-rich oxide nanoparticles located mainly at the grain boundaries. Isothermal oxidation experiments confirm an excellent oxidation resistance due to the formation of protective oxide scales at the very surface. These layers mainly consist of $\mathrm{Cr}_{2} \mathrm{O}_{3}$ and mixed $\mathrm{Y}-\mathrm{W}$ and $\mathrm{Cr}$ $\mathrm{W}$ oxides. The superior oxidation resistance of these alloys is confirmed by tests simulating accident-like conditions. The thermal conductivity of these alloys at $600-1000^{\circ} \mathrm{C}$ is $2-3$ times higher than standard $\mathrm{Ni}$ base superalloys like Inconel-718. The material also exhibits outstanding thermal-shock resistance: 1000 pulses of $0.19 \mathrm{GW} / \mathrm{m}^{2}$ power density and $1 \mathrm{~ms}$ duration at $400^{\circ} \mathrm{C}$ base temperature resulted in no damage, while an increased power density of $0.38 \mathrm{GW} / \mathrm{m}^{2}$ resulted in the formation of a crack-network and slight 
surface roughening. An additional thermal treatment at $1550{ }^{\circ} \mathrm{C}$ improves slightly the oxidation and significantly the thermal shock resistance of the alloy.

\section{Keywords}

Tungsten alloy, self-passivating alloy, oxidation resistance, thermal shock resistance, nuclear fusion, plasma-facing materials

\section{Introduction}

The highest melting point among all metals and a comparably high thermal conductivity make tungsten (W) very attractive for many high temperature applications such as power generation, concentrated solar power, target of spallation sources, and plasma-facing materials (PFM) of future fusion reactors among others. However, the poor oxidation resistance of $\mathrm{W}$ limits its use either to a vacuum environment or to temperatures below $500^{\circ} \mathrm{C}$ in oxidizing environments. In the application as PFM for future fusion reactors such as DEMO, W will be exposed to high steady state heat loads in the $\mathrm{MW} / \mathrm{m}^{2}$ regime, especially at the so-called divertor [1], but the high oxidation rate of $W$ does not represent a concern in a deuterium-tritium plasma environment under normal operation conditions. However, a loss-of-coolant accident (LOCA) with simultaneous air ingress into the vacuum vessel would lead to a temperature rise of the in-vessel components between 1000 and $1200^{\circ} \mathrm{C}$ (depending on the reactor design) within a view to tens of days due to the nuclear afterheat [2]. Under this situation, the use of pure W in DEMO represents a safety risk since part of the $\mathrm{W}$ would oxidize forming volatile $\mathrm{WO}_{3}$ with the potential release of significant amounts of highly radioactively activated species. A possible solution to this important safety issue is the addition of oxide forming alloying elements to pure $\mathrm{W}$, resulting in the growth of a stable protective oxide scale that prevents $W$ from oxidation at high temperatures in presence of oxygen. Under normal operation, the surface of these self-passivating alloys will consist of pure $W$ due to preferential sputtering of the alloying elements by hydrogen isotopes coming from the fusion plasma. A proper selection of the alloying elements is crucial for fusion application since they have to exhibit sufficiently low activation by neutron irradiation from the plasma, in addition to other important properties such as low volume increase of the oxides, low vapor pressure, high melting point and no formation of undesirable intermetalics. For this reason, alloying elements forming stable oxides like $\mathrm{Al}, \mathrm{Nb}$ or $\mathrm{Ni}$ are not permitted because of their high activation by neutrons.

During the last years significant efforts were undertaken to develop self-passivating $W$ alloys for fusion application, starting from thin films of the systems W-Cr-Si and W-Cr-Ti $[3,4]$ which served as "model materials" for the manufacturing of bulk alloys by powder metallurgical (PM) routes [5,6]. More recently, it has been demonstrated that $\mathrm{W}$ alloys of the system $\mathrm{W}-\mathrm{Cr}-\mathrm{Y}$ result in a significant reduction of the oxidation rate at temperatures up to $1000^{\circ} \mathrm{C}$ compared to previously studied ternary systems $[7,8]$. Besides, the

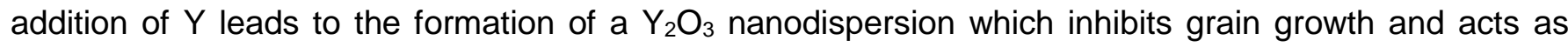
reinforcement, as reported also in $[9,10]$ for pure $\mathrm{W}$.

In this work the most recent developments on self-passivating alloys of the system W-Cr-Y manufactured by PM for application at the DEMO blanket first wall are presented. The purpose of this research is to develop a W-based material with good oxidation resistance due to self-passivation up to at least $1000^{\circ} \mathrm{C}$, 
together with as high as possible thermal conductivity and high mechanical strength. In this way, the material should be able to withstand not only the expected thermal load during normal operation, but also transient thermal loads like the so-called edge localized modes (ELMs), during which a large amount of energy is loaded on the PFMs in a very short time [11]. Results on W-Cr-Y alloys with different $\mathrm{Cr}$ and $\mathrm{Y}$ contents, manufactured by mechanical alloying (MA) and densified by Hot Isostatic Pressing (HIP), are presented. The alloys are subjected to a subsequent heat treatment $(\mathrm{HT})$ at $1550^{\circ} \mathrm{C}$, i.e. above the spinodal decomposition temperature of the $\mathrm{W}$-Cr phase diagram, to dissolve the $\mathrm{Cr}$-rich phase and achieve a single bcc phase [12]. By this means, thermal stresses induced by the second phase, which may appear during thermal shock loads, are avoided $[7,13]$. Microstructural investigations and microhardness of the as HIPed and HIP+ HTed materials are shown and compared to alloys of previous investigations. Thermal conductivity and flexural strength, results of oxidation tests under isothermal and accident-like conditions, as well as thermal shock tests at JUDITH-1 (Juelich Divertor Test Facility Hot Cells) [14] simulating loads under transient events are included.

\section{Experimental}

Elemental powders of pure $\mathrm{W}(99.95 \%, 15-30 \mu \mathrm{m}), \mathrm{Cr}(99.95 \%, 74 \mu \mathrm{m})$ and $\mathrm{Y}(99.9 \%, 20-30 \mu \mathrm{m})$ were used to produce samples of the $\mathrm{W}-\mathrm{Cr}-\mathrm{Y}$ system with $\mathrm{Cr}$ contents of 8 and $10 \mathrm{wt} . \%$ and $\mathrm{Y}$ contents of 0.3 , 0.5 and $1 \mathrm{wt} . \%$. The starting powders were mechanically alloyed under Ar atmosphere in a planetary ball mill using WC grinding jars and balls. The MA parameters were optimized to obtain a homogeneously alloyed powder at the minimum milling time to keep impurities from jars and balls as low as possible. Metallic capsules with the alloyed powder were evacuated, degassed, sealed and HIPed at $1250^{\circ} \mathrm{C}$ for 2 $\mathrm{h}$ at $150 \mathrm{MPa}$. After HIP a heat treatment $(\mathrm{HT})$ was performed at $1550{ }^{\circ} \mathrm{C}$ under $\mathrm{H}_{2}$ atmosphere. The oxygen and nitrogen contents of powders and bulk materials were determined using the inert gas fusion method (ASTM E1569), and the carbon content by the combustion method (ASTM E1019). Powders and bulk samples were characterized by field emission scanning electron microscopy (FE-SEM) and energy dispersive X-ray spectroscopy (EDS). The relative density of the samples was determined from the geometrical and theoretical densities. The average grain size of the dense materials was determined by quantitative metallography. The Vickers microhardness was measured applying a load of $0.5 \mathrm{~kg}$ for 5 seconds. Three-point bending tests (3PBT) were performed on smooth and single edge laser-notched beams [15] of nominal dimensions $1.8 \times 1.8 \times 20 \mathrm{~mm}^{3}$ over the temperature range $20-1100{ }^{\circ} \mathrm{C}$ under high vacuum. All tests were performed in displacement control at a fixed loading rate of $100 \mu \mathrm{m} / \mathrm{min}$ with a $16 \mathrm{~mm}$ span width. Flexural strength was computed by Euler-Bernoulli equations for slender beams up to failure. However, when yield stress was exceeded, the $0.2 \%$ strength offset was reported. Fracture toughness, i.e. the stress intensity factor for mode I stress, was then computed from the critical load and the beam section using the equation proposed by Guinea et al. [16]. The thermal conductivity was measured by the laser flash method.

Isothermal oxidation tests at $800^{\circ} \mathrm{C}$ and $1000^{\circ} \mathrm{C}$ for up to $60 \mathrm{~h}$ were performed by thermogravimetric analysis (TGA) using a mixture of $80 \% \mathrm{Ar}$ and $20 \% \mathrm{O}_{2}$ at atmospheric pressure. The mass gain of the samples due to oxide formation was measured by a thermobalance with a sensitivity of $0.025 \mu \mathrm{g}$. The procedure is described in detail in [4]. Besides, oxidation tests simulating accident-like conditions were also performed. These tests consist of a preheating in $\operatorname{Ar} 6.0$ up to $600^{\circ} \mathrm{C}$ followed by oxidation in a mixture of $80 \mathrm{vol} . \% \mathrm{Ar}$ and $20 \mathrm{vol} . \% \mathrm{O}_{2}$ at linear increasing temperature from 600 to $1000^{\circ} \mathrm{C}$ during about $17 \mathrm{~h}$, two isothermal oxidation steps in air at $1000^{\circ} \mathrm{C}$ for $1 \mathrm{~h}$, each of them followed by isothermal steps in $\operatorname{Ar} 6.0$ 
at $1000^{\circ} \mathrm{C}$ for $1 \mathrm{~h}$, and cooling down in Ar. Surfaces and cross sections of the oxidized samples were analyzed by FE-SEM and Focused Ion Beam (FIB).

Thermal shock tests were performed at the electron beam facility JUDITH-1 [14] on samples of dimensions $10 \times 10 \times 4 \mathrm{~mm}^{3}$, which were exposed at a base temperature of $400^{\circ} \mathrm{C}$ to loads consisting of 1000 pulses with power densities of 0.19 and $0.38 \mathrm{GW} / \mathrm{m}^{2}$ for $1 \mathrm{~ms}$ simulating the conditions expected at the divertor under ELMs. To ensure a homogeneous loading, a small area $\left(4 \times 4 \mathrm{~mm}^{2}\right)$ was scanned with a focused electron beam at very high scanning frequencies. After exposure, the surface and cross section of the samples were investigated by optical microscopy.

\section{Results and discussion}

Mechanically alloyed powders of compositions (in wt.\%) W-8Cr-0.5Y, W-10Cr-0.3Y, W-10Cr-0.5Y and W$10 \mathrm{Cr}-1 \mathrm{Y}$ (corresponding to $\mathrm{W}-23 \mathrm{Cr}-0.9 \mathrm{Y}, \mathrm{W}-28 \mathrm{Cr}-0.5 \mathrm{Y}, \mathrm{W}-28 \mathrm{Cr}-0.8 \mathrm{Y}$ and $\mathrm{W}-28 \mathrm{Cr}-1.6 \mathrm{Y}$ in at.\%, respectively) were can encapsulated and HIPed at $1250{ }^{\circ} \mathrm{C}$ for $2 \mathrm{~h}$, achieving relative densities $>99 \%$ (Table 1), i.e. the materials are fully dense within the experimental error. The contents of interstitial elements after MA amount to $1200-1500$ ppm for oxygen, $100-160$ ppm for nitrogen and $200-400$ ppm for carbon, and remain the same after HIP.

Table 1: Relative density, average grain size and microhardness of W-Cr-Y alloys of different compositions after $\mathrm{HIP}$ at $1250^{\circ} \mathrm{C}$ and after subsequent $\mathrm{HT}$ at $1550^{\circ} \mathrm{C}$ (only for W-10Cr-0.5Y).

\begin{tabular}{|c|c|c|c|c|c|}
\hline \multirow[t]{2}{*}{ Alloy composition } & \multirow{2}{*}{$\begin{array}{l}\mathrm{HT} \text { at } \\
1550^{\circ} \mathrm{C}\end{array}$} & \multirow{2}{*}{$\begin{array}{l}\text { Relative density } \\
(\%)\end{array}$} & \multirow{2}{*}{$\begin{array}{l}\text { Average grain } \\
\text { size }(\mu \mathrm{m})\end{array}$} & \multicolumn{2}{|l|}{ Microhardness } \\
\hline & & & & Alloys $\left(\mathrm{HV}_{0.5}\right)$ & Pure W (HV) [21] \\
\hline W-8Cr-0.5Y & No & 99.1 & $102 \pm 3$ & $1265 \pm 4$ & 1340 \\
\hline W-10Cr-0.3Y & No & 99.8 & $84 \pm 3$ & $1145 \pm 3$ & 1441 \\
\hline$W-10 C r-0.5 Y$ & No & 99.8 & $110 \pm 4$ & $1220 \pm 8$ & 1304 \\
\hline W-10Cr-1Y & No & 99.6 & $228 \pm 8$ & $1190 \pm 8$ & 1012 \\
\hline W-10Cr-0.5Y & Yes & 98.7 & $230 \pm 11$ & $980 \pm 6$ & 1009 \\
\hline
\end{tabular}

Besides, a HT after HIP was performed on alloy $\mathrm{W}-10 \mathrm{Cr}-0.5 \mathrm{Y}$ at $1550^{\circ} \mathrm{C}$, i.e. at a temperature above the spinodal decomposition of the $\mathrm{W}-\mathrm{Cr}$ phase diagram, see Fig. 1. According to this phase diagram, after HIPing at $1250^{\circ} \mathrm{C}$ two bcc phases are formed: a $(\alpha \mathrm{W}, \mathrm{Cr})$ main phase with minor presence of $(\alpha \mathrm{Cr}, \mathrm{W})$. The compositions of these two phases were estimated from the shift of the peaks obtained by X-ray diffraction (XRD) with respect to the pure $\mathrm{W}$ and $\mathrm{Cr}$ peaks. These compositions are indicated by the blue lines in the phase diagram of Fig. 1, and agree well with the predictions of the phase diagram at $1250^{\circ} \mathrm{C}$. The purpose of this $\mathrm{HT}$ is to dissolve the $\mathrm{Cr}$-rich phase, more prone to oxidation, and to produce a single phase material (see red cross and lines in Fig. 1) in which misfit strains and thermal stresses induced by the second phase are avoided. $\mathrm{HT}$ temperatures higher than $1550^{\circ} \mathrm{C}$ are avoided due to the presence of an eutectic $\mathrm{W}-\mathrm{Y}_{2} \mathrm{O}_{3}$ at $1560^{\circ} \mathrm{C}$ [17], which would lead to a significant grow of the $\mathrm{Y}_{2} \mathrm{O}_{3}$ nanoparticles (described in section 3.1).

After the $\mathrm{HT}$, the content of interstitials remains practically unchanged. A slight reduction of relative density is observed after $\mathrm{HT}$, which may be related to residual Ar gas trapped in the powders during MA [18]; during HIPing the Ar containing micro-pores collapse and a nearly dense material is obtained due to the 
high pressure applied. However, if a HT without pressure is performed at a temperature higher than the one of the HIP cycle, the small pores grow contributing to the formation of so-called temperature induced porosity [19].

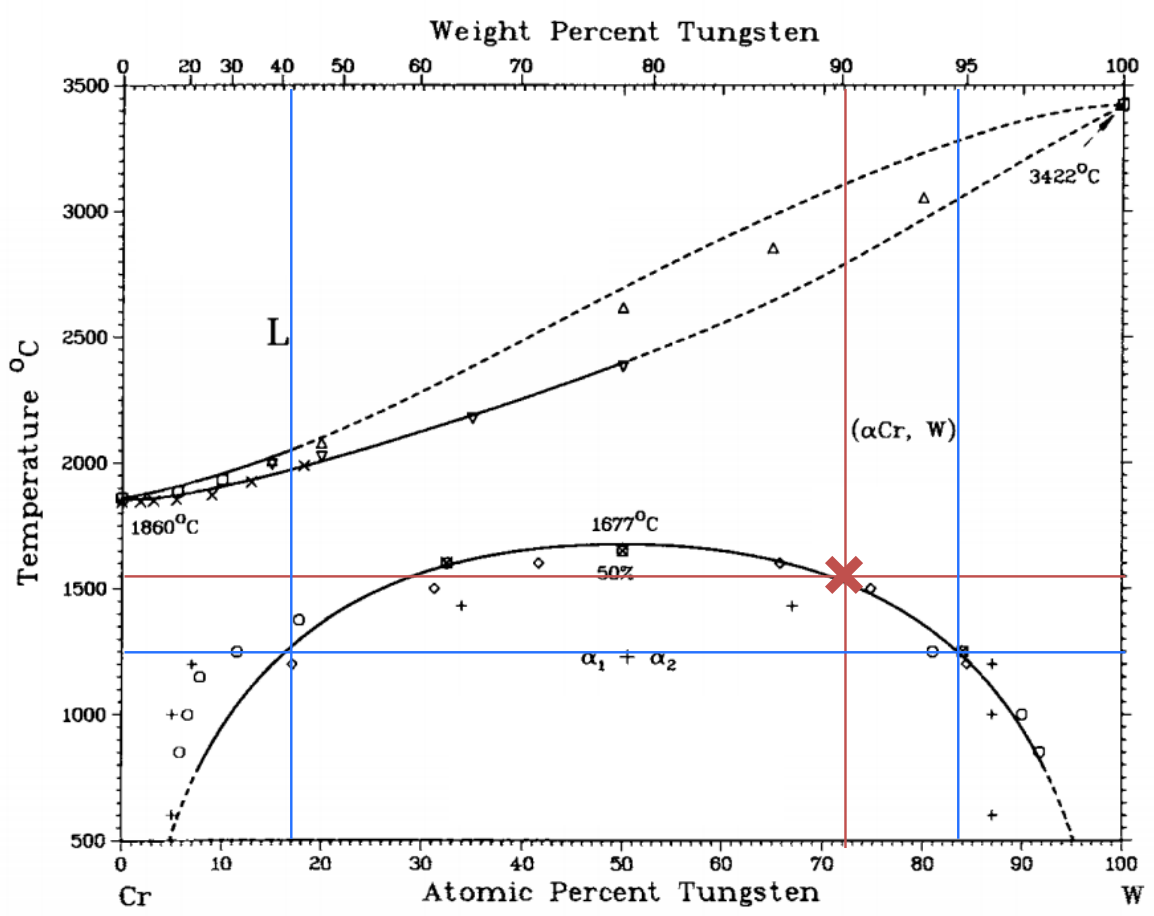

Figure 1: W-Cr phase diagram [12] indicating the composition in the W-10Cr-0.5Y alloy of the bcc ( $\alpha \mathrm{W}, \mathrm{Cr}$ ) and ( $\alpha \mathrm{Cr}, \mathrm{W})$ phases after HIP deduced from the peak positions of the corresponding XRD peaks (blue lines). The composition of the single bcc phase expected after $\mathrm{HT}$ at $1550{ }^{\circ} \mathrm{C}$ is indicated (red cross and lines).

\subsection{Microstructure}

After HIP, a very fine and homogeneous microstructure can be appreciated in all alloys (Fig 2 (a)-(c)), with two main phases identified by EDS as a W-rich phase with $\mathrm{Cr}$ in solution ( $(\alpha \mathrm{W}, \mathrm{Cr})$, bright grey majority phase) and a Cr-rich phase with $W$ in solution $((\alpha C r, W)$, dark grey discontinuous phase). This microstructure and the composition of the phases determined by XRD are consistent with the predictions of the $\mathrm{W}$-Cr phase diagram at $1250{ }^{\circ} \mathrm{C}$, Fig. 1. For the alloys containing 0.3 and $0.5 \% \mathrm{Y}$ the average grain size of the matrix is of the order of $100 \mathrm{~nm}$ (see Table 1), i.e. considerably finer than that of the binary system $\mathrm{W}-15 \mathrm{Cr}$ described in [7], indicating that $Y$ acts as grain growth inhibitor, as reported in [9,10]. A dispersion of $\mathrm{Y}_{2} \mathrm{O}_{3}$ nanoparticles of about $15 \mathrm{~nm}$ size is formed mainly at the grain boundaries (GB) as a result of the decomposition of less stable oxides during HIPing and the high oxygen affinity of $Y$, which reacts with the $O$ introduced in the alloy during MA. This cleaning effect of GB from oxygen together with the grain refinement are supposed to be beneficial for improving the alloy's strength at high temperature $[9,10,20]$. For a $Y$ content of $1 \%$ the amount of oxygen present in the material is not enough to form $\mathrm{Y}_{2} \mathrm{O}_{3}$, i.e. there is an excess of $\mathrm{Y}$. This leads to coarsening of the $\mathrm{Y}$-O-rich nanoparticles and thus, to a less efficient inhibition of grain growth: as can be seen in Table 1 and Fig 2 (c), the matrix grain size in this case is above $200 \mathrm{~nm}$. 
The microstructure of the $\mathrm{W}-10 \mathrm{Cr}-0.5 \mathrm{Y}$ alloy after $\mathrm{HT}$ at $1550{ }^{\circ} \mathrm{C}$ is shown in Fig. 2 (d) and consists of a single $(\alpha \mathrm{W}, \mathrm{Cr})$ phase, as expected from the $\mathrm{W}-\mathrm{Cr}$ phase diagram. Residual particles of $(\alpha \mathrm{Cr}, \mathrm{W})$ phase can be also found. As a consequence of the HT, grain growth up to $230 \mathrm{~nm}$ is observed in the matrix (Table 1), as well as a thickening of the $\mathrm{Y}$-rich oxide nanoparticles, up to about $50 \mathrm{~nm}$.
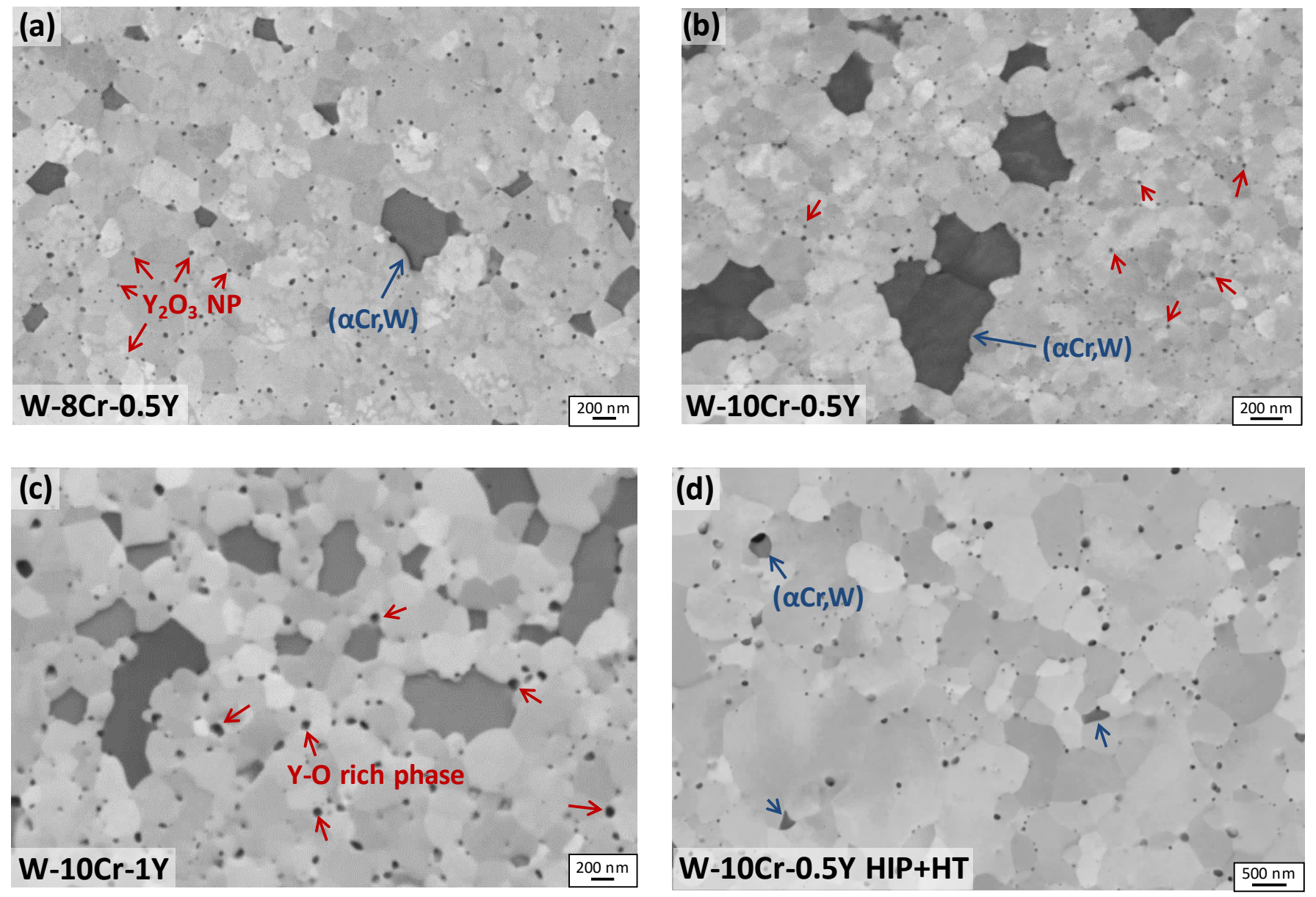

Figure 2: Microstructure after HIP of (a) W-8Cr-0.5Y alloy, (b) W-10Cr-0.5Y alloy, (c) W-10Cr-1Y alloy, and (d) of W-10Cr-0.5Y alloy after HIP + HT.

\subsection{Microhardness and thermal conductivity}

The Vickers microhardness of all alloys after HIP and of W-10Cr-0.5Y alloy after HIP + HT is listed in Table 1. As reference, the micro-hardness of pure polycrystalline $W$ at the corresponding average grain size is included, taking into account its Hall-Petch relation-ship of pure W [21]. For the alloys containing 0.3 and $0.5 \% \mathrm{Y}$ both as-HIPed and HIP+HTed, these values are only slightly lower than those of pure $\mathrm{W}$ at the corresponding grain size. Even though a comparison with pure $\mathrm{W}$ is not straightforward because our alloys have a significant amount of $\mathrm{Cr}$, and because other hardening mechanisms like solution and precipitation hardening may be also present, it can be nevertheless stated that there is a strong influence of grain size on hardening.

The thermal conductivity as a function of temperature of the as HIPed alloys $\mathrm{W}-8 \mathrm{Cr}-0.5 \mathrm{Y}, \mathrm{W}-10 \mathrm{Cr}-0.5 \mathrm{Y}$ and $\mathrm{W}-10 \mathrm{Cr}-1 \mathrm{Y}$ is shown in Fig. 3 together with that of the binary alloy $\mathrm{W}-10 \mathrm{Cr}$ and of Inconel 718 for comparison. The thermal conductivity of all $\mathrm{W}-\mathrm{Cr}-\mathrm{Y}$ alloys is similar in the whole temperature range. The 
slight decrease of thermal conductivity of the W-Cr-Y alloys compared to the binary system W-10Cr may indicate that a small amount of $Y$ is in solid solution. Compared to Inconel 718 , the thermal conductivity of the $\mathrm{W}-\mathrm{Cr}-\mathrm{Y}$ alloys at $600-900^{\circ} \mathrm{C}$ is about 2.5 times higher than Inconel 718 . As a consequence, the resulting temperature increase for a thickness of $2 \mathrm{~mm}$ is $<100 \mathrm{~K}$ and thus, not of concern for the intended application as PFM of the DEMO blanket with expected power densities $<2 \mathrm{MW} / \mathrm{m}^{2}$ [22].

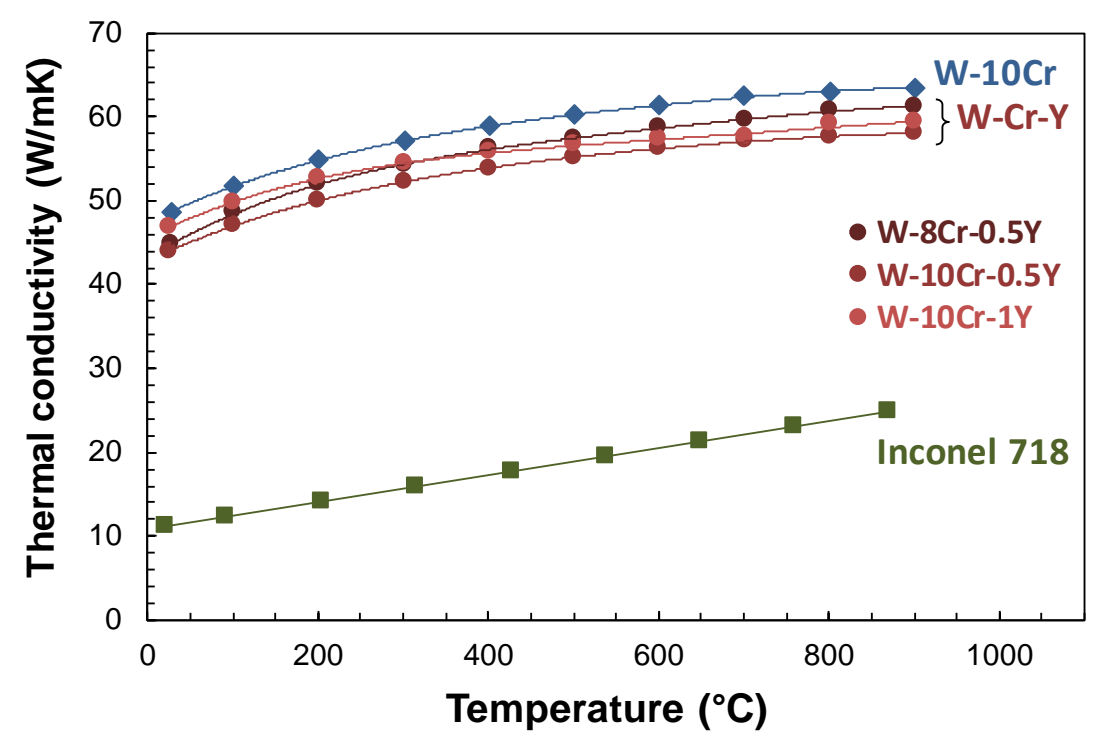

Figure 3: Thermal conductivity as a function of temperature of binary alloy W-10Cr, ternary alloys W-Cr-Y and Inconel 718 for comparison.

\subsection{Mechanical properties}

Non-standard 3PBT tests were performed on both as-HIPed and after HT W-10Cr-0.5Y alloys from $25{ }^{\circ} \mathrm{C}$ to $1100{ }^{\circ} \mathrm{C}$ to explore their mechanical response, i.e. fracture toughness and flexural strength.

Toughness values are plotted as a function of temperature in Fig. 4. Both materials exhibited similar behavior at temperatures above $600{ }^{\circ} \mathrm{C}$, with toughness values around $6 \mathrm{MPa} \cdot \mathrm{m}^{1 / 2}$, which are almost maintained above this temperature. However, at lower temperatures, fracture values of the $\mathrm{W}-10 \mathrm{Cr}-0.5 \mathrm{Y}$ alloy after HT were $30 \%$ higher than these of the as HIPed alloy. The reduction of the Cr-rich phase with $W$ in solution $(\alpha \mathrm{Cr}, \mathrm{W})$, which is indeed the weakest phase of the system, together with the improved adhesion as a consequence of the grain growth could be the reason of this behavior.

From the flexural strength tests (Fig. 5 (a) and (b)) it can be observed that both specimens showe brittle behavior up to $900^{\circ} \mathrm{C}$ while some plastic deformation takes place at $950^{\circ} \mathrm{C}$. Above $1000^{\circ} \mathrm{C}$, the material clearly exhibits plastic deformation. Thus, the ductile-to-brittle transition temperature (DBTT) lies around $950^{\circ} \mathrm{C}$. At $1100^{\circ} \mathrm{C}$ the material deforms plastically without breaking. Although the $\mathrm{W}$-Cr-Ti system presented a similar DBTT [5], some decrease was expected taking into account the grain size reduction [23], but there is no variation though. Most probably, the $Y$-rich nanoparticles contribute to reinforcement but not to ductilization because they are located mainly at the GB contributing to their weakening. In fact, the fracture is intergranular for all tested temperatures up to $1050^{\circ} \mathrm{C}$ across the $\mathrm{W}$-rich phase. Above $900^{\circ} \mathrm{C}$ there is some transgranular fracture across the $\mathrm{Cr}$-rich grains. 


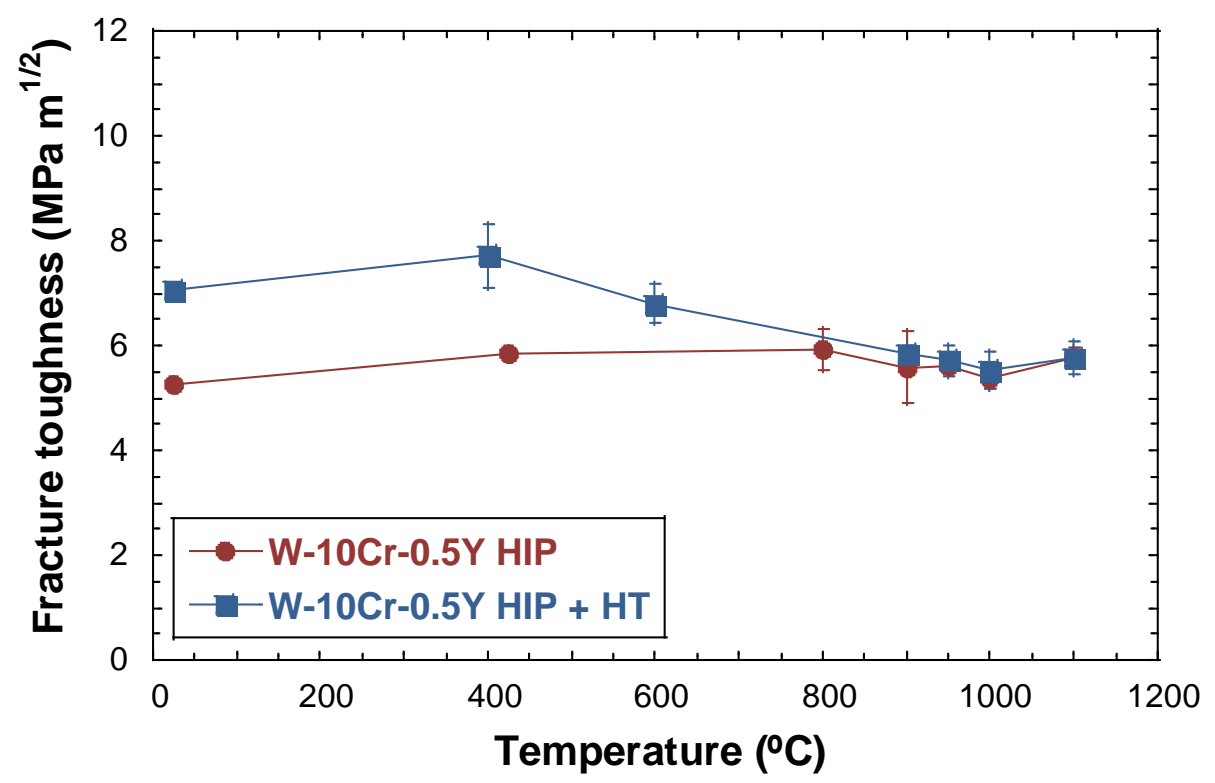

Figure 4: Average fracture toughness versus test temperature for $\mathrm{W}-10 \mathrm{Cr}-0.5 \mathrm{Y}$ materials. Mean values and standard error.

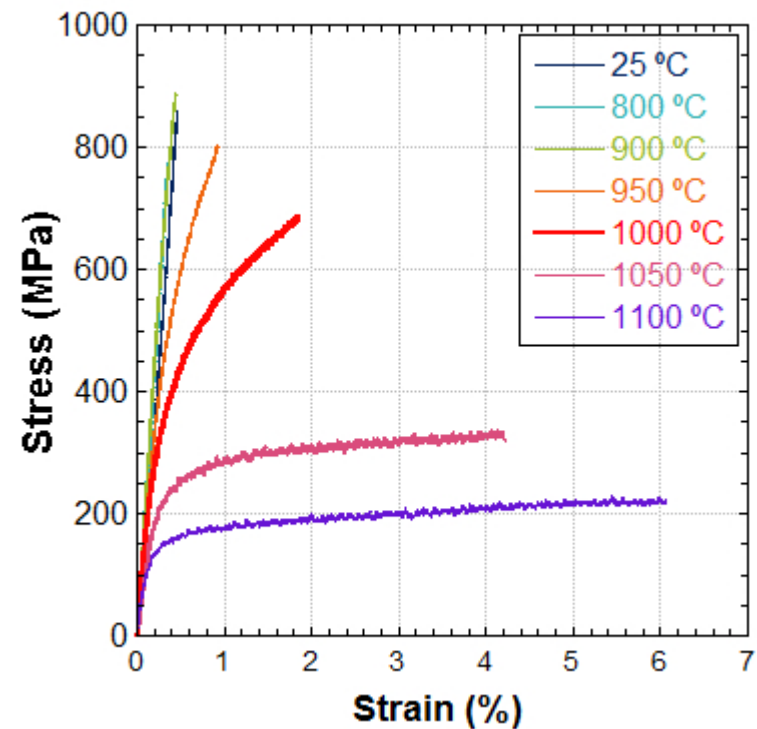

a)

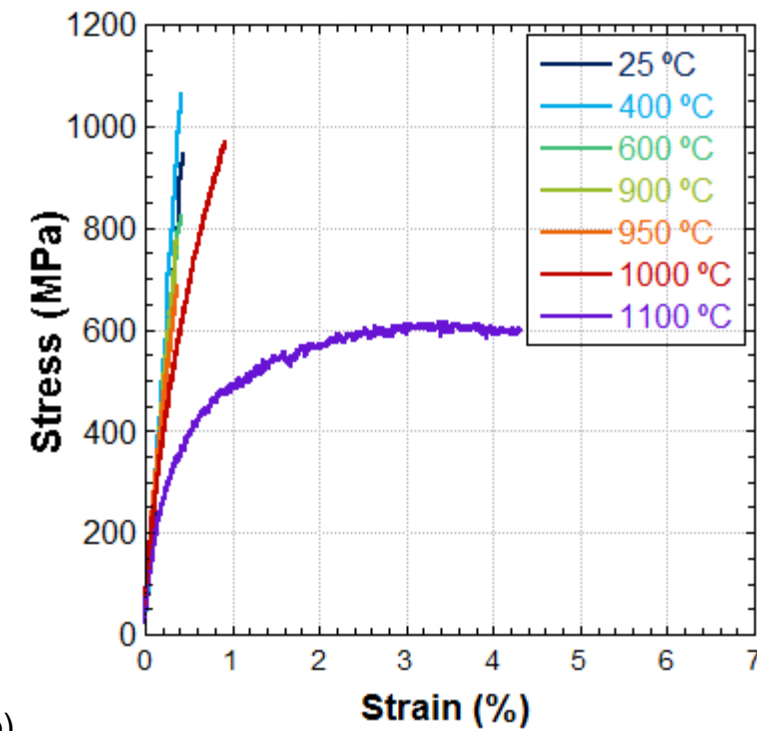

b)

Figure 5: Flexural strength vs strain from $25^{\circ} \mathrm{C}$ up to $1100^{\circ} \mathrm{C}$ of (a) W-10Cr-0.5Y alloy after HIP, and (b) after HIP $+\mathrm{HT}$.

The proof flexural strength of both alloys can be observed in Fig. 6, where ultimate flexural strength is plotted as a function of temperature. Above the DBTT, the $0.2 \%$ yield strength offset is used and represented with dashed lines and open symbols. Both materials maintained the strength between RT and $900{ }^{\circ} \mathrm{C}$, but then the strength decreases slightly. As observed for the fracture toughness, the effect of the $\mathrm{HT}$ is noticeable just at temperatures below the DBTT. Above this temperature its strength decreases slightly compared to the as HIPed material. 


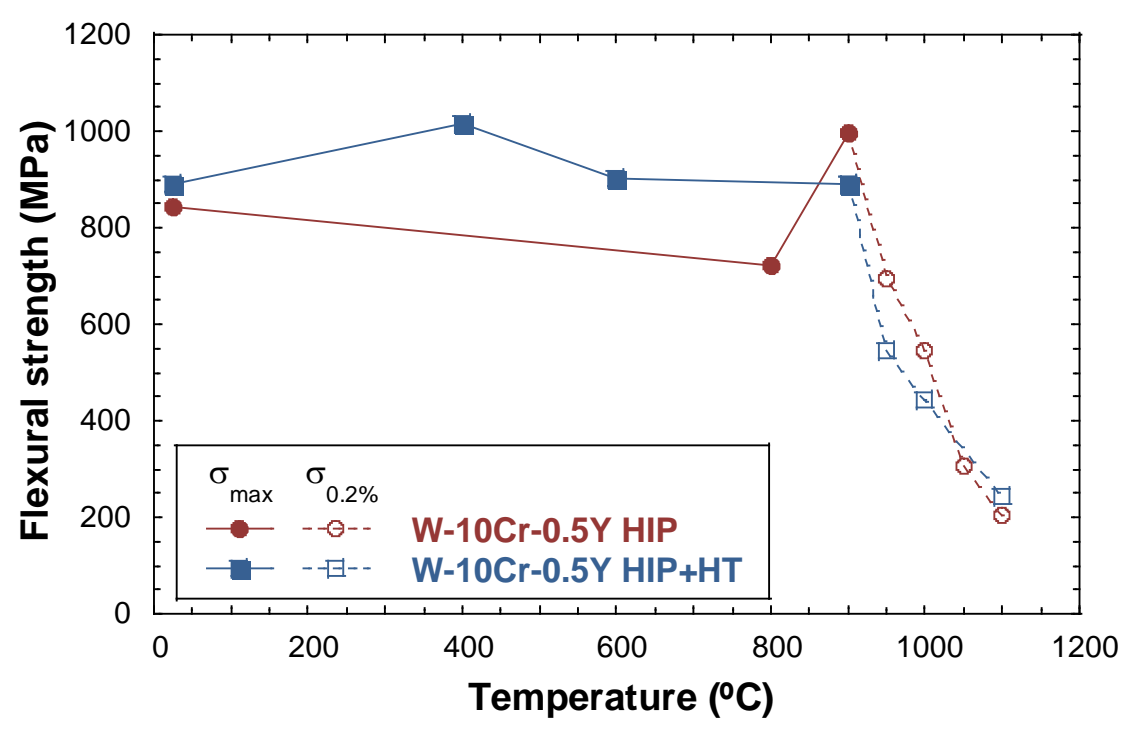

Figure 6: Proof flexural strength as a function of temperature for the as HIPed W-10Cr-0.5Y alloy and the alloy after after HIP + HT. Mean values and standard error. Full symbols and continuous lines illustrate brittle behavior and hence, ultimate flexural strength instead of yield strength.

\subsection{Oxidation tests}

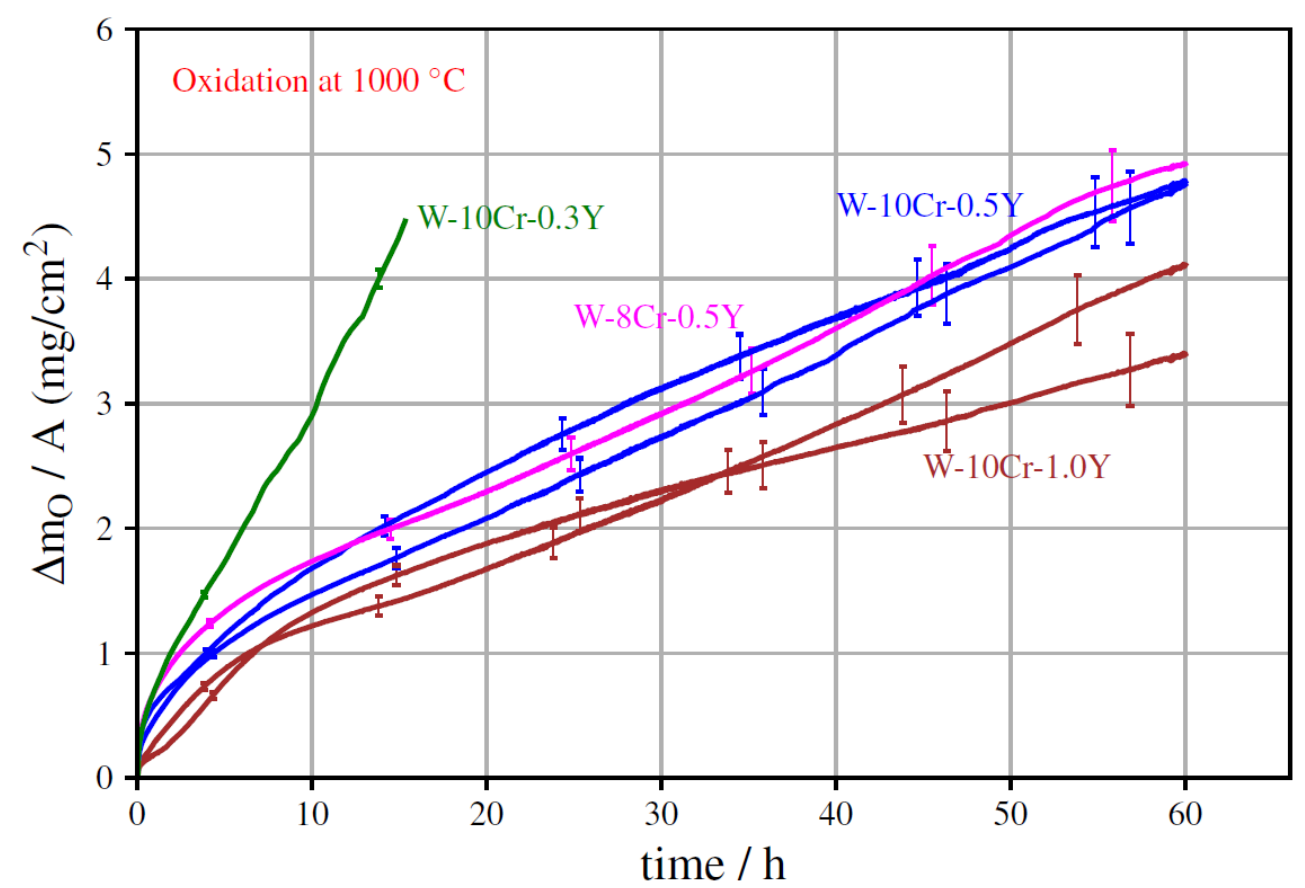

Figure 7: Mass gain per unit area during isothermal oxidation of different as-HIPed W-Cr-Y alloys at $1000^{\circ} \mathrm{C}$. The error bars correspond to the drift of the thermos-balance provided by the TGA manufacturer. Lines of the same colors correspond to repetition of the measurement with a new sample.

Isothermal oxidation tests at $800^{\circ} \mathrm{C}$ and $1000{ }^{\circ} \mathrm{C}$ for up to $60 \mathrm{~h}$ were performed on $\mathrm{W}-\mathrm{Cr}-\mathrm{Y}$ alloys of different $\mathrm{Cr}$ and $\mathrm{Y}$ contents. The mass gain per unit area of each alloy during isothermal oxidation at $1000^{\circ} \mathrm{C}$ is shown in Fig. 7. The error bars corresponds to the drift of the TGA thermo-balance of $5 \mu \mathrm{g} / \mathrm{h}$ provided by the manufacturer (Netzsch) and increase, thus, with increasing exposure time. Lines of the 
same color in Fig. 7 correspond to a second measurement with a new sample to assure the reproducibility, which appears to be satisfactory. For alloys containing 0.5 and $1 \% \mathrm{Y}$, the initially parabolic kinetics transform into linear for longer exposure times. Alloy of composition W-10Cr-1Y exhibit the lowest oxidation rate of all investigated alloys so far [6,7], while an $\mathrm{Y}$ content of $0.3 \% \mathrm{Y}$ results in a significantly higher oxidation rate, indicating that $0.3 \mathrm{Y}$ does not provide sufficient protection against oxidation. The difference between the oxidation rates of alloys $\mathrm{W}-8 \mathrm{Cr}-0.5 \mathrm{Y}$ and $\mathrm{W}-10 \mathrm{Cr}-0.5 \mathrm{Y}$ does not seems relevant.

In the Arrhenius plot of Fig. 8 the linear oxidation rates of pure W, W-10Cr-0.5Y, W-10Cr-1Y (measured at 1000 and $1100^{\circ} \mathrm{C}$ ) and $\mathrm{W}-12 \mathrm{Cr}-0.5 \mathrm{Y}$ (the latter from [7] and only for $800^{\circ} \mathrm{C}$ ) are shown vs the inverse of temperature. At $800^{\circ} \mathrm{C}$ the oxidation rates of $\mathrm{W}-10 \mathrm{Cr}-0.5 \mathrm{Y}$ alloy are four orders of magnitude lower than pure $\mathrm{W}$, and at $1000^{\circ} \mathrm{C}$ the ones of $\mathrm{W}-10 \mathrm{Cr}-0.5 \mathrm{Y}$ and $\mathrm{W}-10 \mathrm{Cr}-1 \mathrm{Y}$ are about three orders of magnitude lower than pure $\mathrm{W}$.

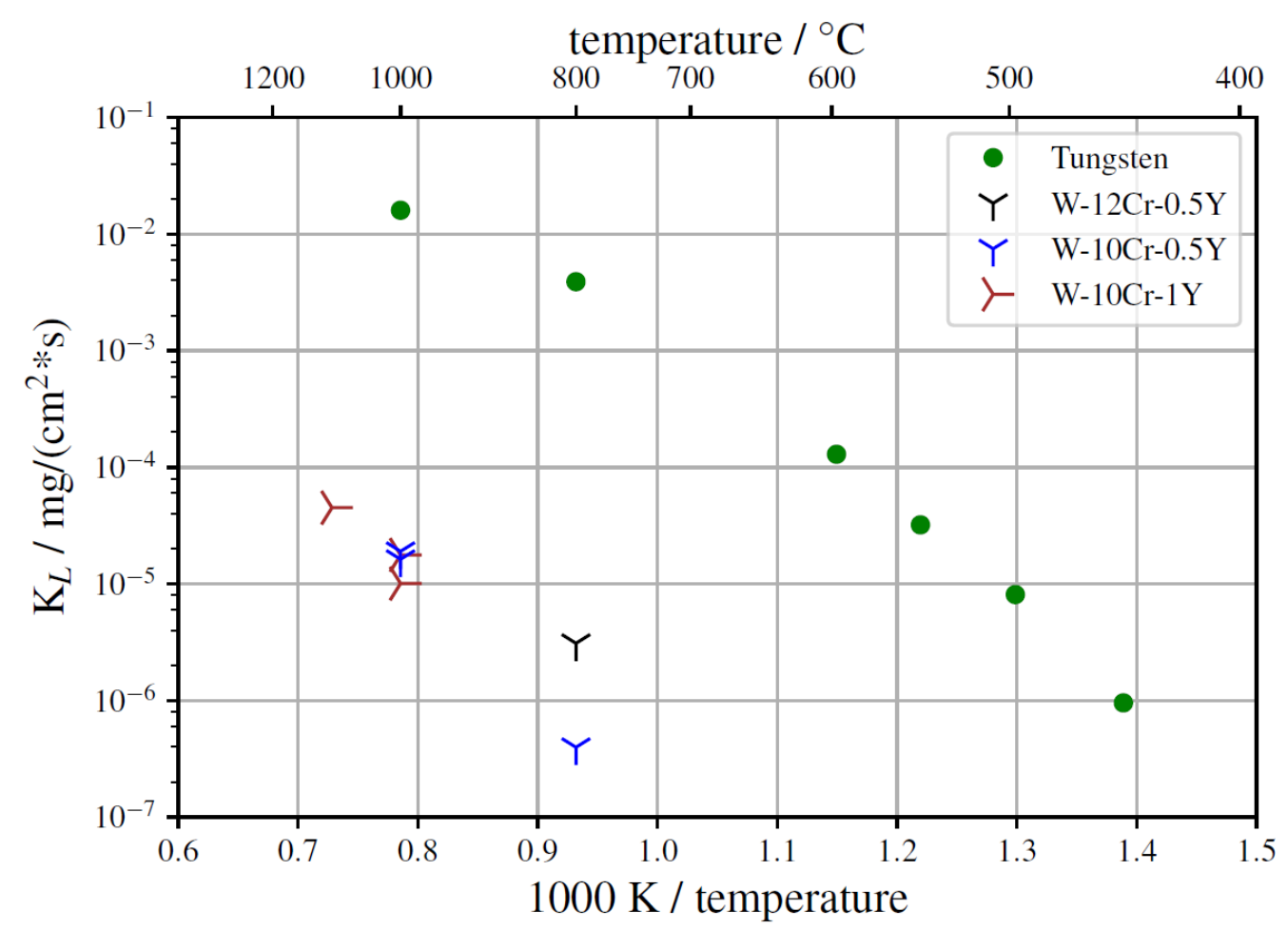

Figure 8: Arrhenius plot of linear oxidation rates of as-HIPed W-Cr-Y alloys and pure W for comparison. Data for W-12Cr-0.5Y are taken form [7].

In Fig. 9 the mass gain per unit area during tests simulating accident-like conditions up to $1000^{\circ} \mathrm{C}$ is shown for as-HIPed W-Cr-Y alloys of different composition as well as for the W-10Cr-2Ti alloy of previous work [7] for comparison. Alloys of the $\mathrm{W}-\mathrm{Cr}-\mathrm{Y}$ system exhibit the lowest mass gain of all investigated alloys, except the one with $0.3 \% \mathrm{Y}$, which starts failing at about $800^{\circ} \mathrm{C}$ after about $9 \mathrm{~h}$ exposure to synthetic air. The $\mathrm{W}-10 \mathrm{Cr}-1 \mathrm{Y}$ alloy exhibit the lowest oxidation rate, in agreement with the isothermal oxidation tests (Fig. 7). Under accident-like conditions the $\mathrm{W}-10 \mathrm{Cr}-0.5 \mathrm{Y}$ alloy results in slightly better oxidation resistance than the $\mathrm{W}-8 \mathrm{Cr}-0.5 \mathrm{Y}$ one, and in clearly lower mass gains than the $\mathrm{W}-12 \mathrm{Cr}-0.5 \mathrm{Y}$ one, indicating that $10 \%$ $\mathrm{Cr}$ provides better oxidation protection than 8 and $12 \% \mathrm{Cr}$. This is only partly in agreement with the findings of [8] , where the optimum $\mathrm{Cr}$ and $\mathrm{Y}$ concentration for lowest oxidation rate in isothermal oxidation tests at $1000^{\circ} \mathrm{C}$ was investigated for thin films produced by magnetron sputtering. In this work lowest oxidation rate were found for $11.4 \% \mathrm{Cr}$ with a very slight increase for concentrations beyond $12 \%$ and significantly 
higher rates for about $10 \% \mathrm{Cr}$. One has to take into account that a comparison between bulk materials and thin films is not straightforward because of the many microstructural differences between the two systems. Samples of alloys $\mathrm{W}-10 \mathrm{Cr}-0.5 \mathrm{Y}$ and $\mathrm{W}-10 \mathrm{Cr}-2 \mathrm{Ti}$ subjected to HT were studied in [13] and [7], respectively, showing only a slight decrease in mass gain with respect to the as-HIPed material. In Fig. 9 it can be observed that the mass increase of all alloys W-Cr-Y alloys (except the W-10Cr-0.3Y one) follows a parabolic law at the second isothermal segments. Another important observation is the fact that in the isothermal segments without oxygen there is no mass loss, indicating that there is no evaporation of tungsten oxide, previously formed during the oxidation segment.

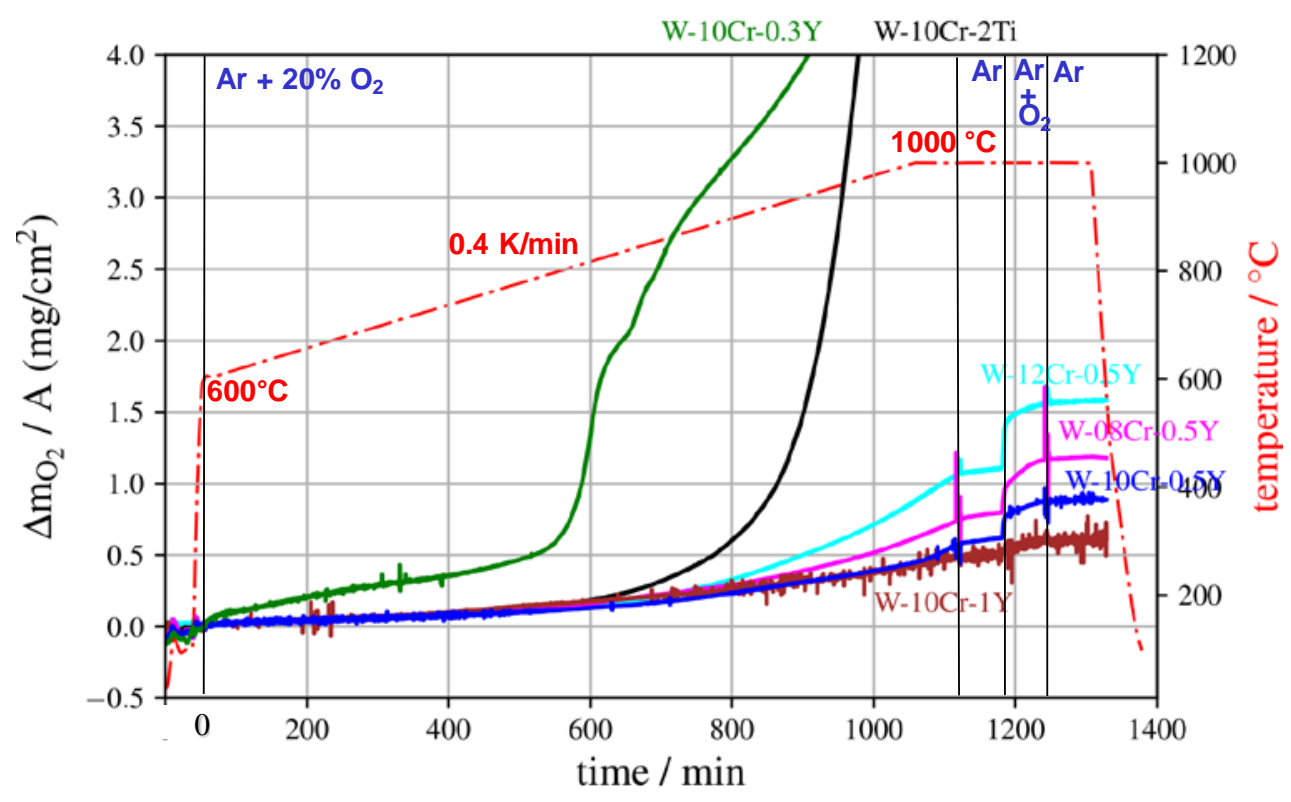

Figure 9: Mass increase per unit area during tests simulating accident-like conditions on different as HIPed W-Cr-Y alloys, and comparison with previous works [6, 7]. After preheating in $\operatorname{Ar}$ up to $600^{\circ} \mathrm{C}$, synthetic air is introduced and temperature is increased linearly from 600 to $1000^{\circ} \mathrm{C}$, followed by $1 \mathrm{~h}$ isothermal oxidation in air at $1000^{\circ} \mathrm{C}$, an isothermal step in pure Ar for $1 \mathrm{~h}$, repetition of the two isothermal steps and cooling down in Ar.

The surface and cross-sections of the formed scales both after isothermal and accident-like oxidation were analyzed by FE-SEM, FIB and EDS. In Fig. 10 the cross-sections of the W-10Cr-0.5Y and W-10Cr-1Y alloys after accident-like oxidation are presented. In both cases, three layers can be distinguished: a thin $\mathrm{Cr}_{2} \mathrm{O}_{3}$ scale and a thin $\mathrm{Cr}_{2} \mathrm{WO}_{6}$ layer just below, followed by a thicker $\mathrm{WO}_{3}$ layer. Partial oxidation of the $(\alpha \mathrm{Cr}, \mathrm{W})$ phase located below and near the scales can be also observed, as well as a dark phase along the $\mathrm{GB}$ identified as $\mathrm{Cr}_{2} \mathrm{O}_{3}$, indicating diffusion of cations and anions along the GB. After isothermal oxidation with longer exposure times than the accident-like tests, $\mathrm{W}-\mathrm{Y}$ mixed oxides can be appreciated above and inside the thin $\mathrm{Cr}_{2} \mathrm{O}_{3}$ layer. Analysis of these mixed oxides by grazing incidence XRD and EDS allowed their identification as $\mathrm{Y}_{2} \mathrm{~W}_{3} \mathrm{O}_{12}$, in agreement with the findings of Telu et al. in the system W-Cr$\mathrm{Y}_{2} \mathrm{O}_{3}$ [24]. This mixed oxide has been also found to a much lesser extent after $60 \mathrm{~h}$ isothermal oxidation at $800^{\circ} \mathrm{C}$. 

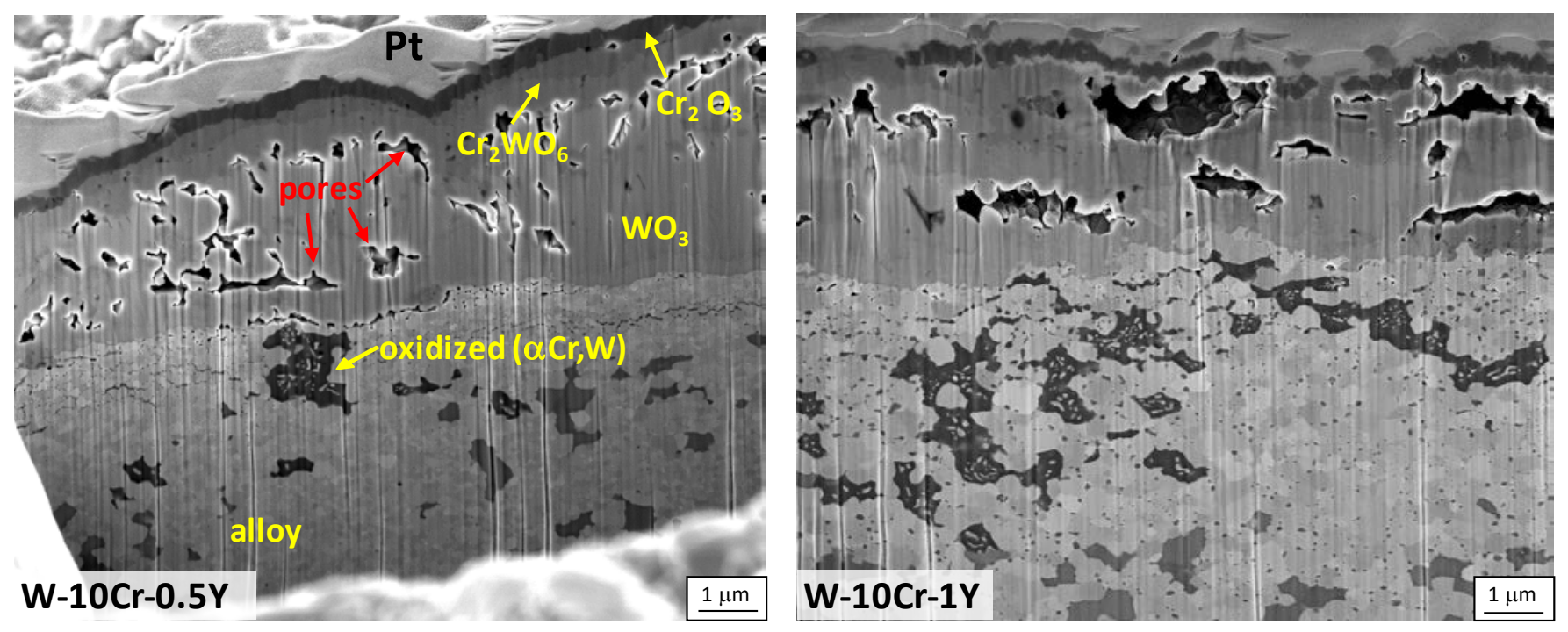

Figure 10: Cross-section of (left) as-HIPed W-10Cr-0.5Y and (right) W-10Cr-1Y alloys after the accident-like oxidation tests.
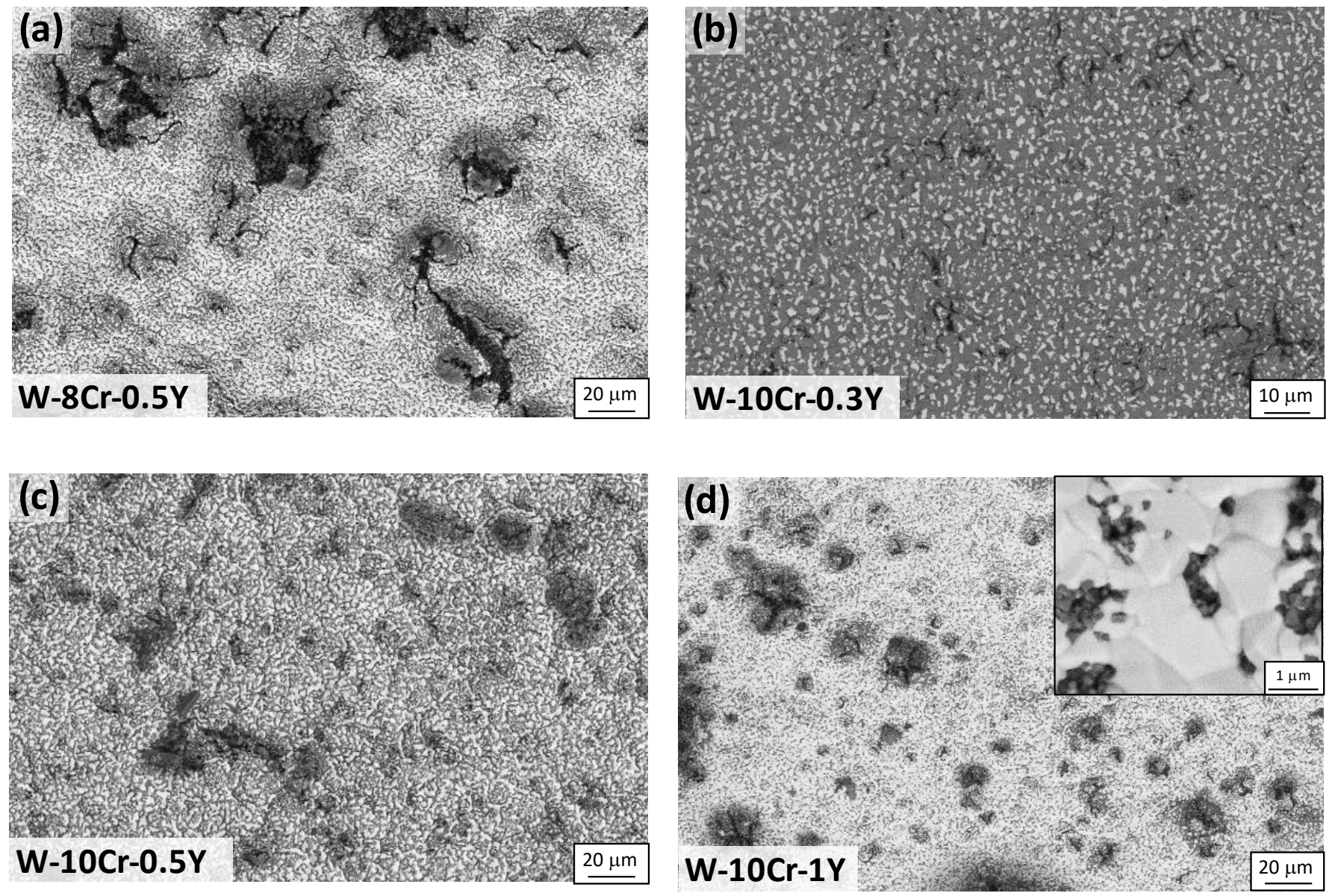

Figure 11: Surface of alloys (a) W-8Cr-0.5Y, (b) W-10Cr-0.3Y, (c) W-10Cr-0.5Y, and (d) W-10Cr-1Y alloy after $24 \mathrm{~h}$ isothermal oxidation at $1000^{\circ} \mathrm{C}$. 
The surface of the alloys $\mathrm{W}-8 \mathrm{Cr}-0.5 \mathrm{Y}, \mathrm{W}-10 \mathrm{Cr}-0.3 \mathrm{Y}$ alloy, $\mathrm{W}-10 \mathrm{Cr}-0.5 \mathrm{Y}$ and $\mathrm{W}-10 \mathrm{Cr}-1 \mathrm{Y}$ after $24 \mathrm{~h}$ isothermal oxidation at $1000^{\circ} \mathrm{C}$ is shown in Fig. 11 . A network of white particles corresponding to the $\mathrm{Y}_{2} \mathrm{~W}_{3} \mathrm{O}_{12}$ oxide can be appreciated. The alloy with $1 \% \mathrm{Y}$ exhibits the highest $\mathrm{Y}_{2} \mathrm{~W}_{3} \mathrm{O}_{12}$ particle density, almost covering the thin $\mathrm{Cr}_{2} \mathrm{O}_{3}$ layer, which has the aspect of small black particles (s. insert in Fig. 11 (d)). In the alloy with $0.3 \% \mathrm{Y}$ the $\mathrm{Y}_{2} \mathrm{~W}_{3} \mathrm{O}_{12}$ particles are very dispersed above the $\mathrm{Cr}_{2} \mathrm{O}_{3}$ layer (Fig. 11 (b), while in the alloys with $0.5 \% \mathrm{Y}$ (Fig. 11 (a) and (c)) these particles start to cover the $\mathrm{Cr}_{2} \mathrm{O}_{3}$ layer. In the alloy with $8 \% \mathrm{Cr}$ the $\mathrm{Cr}_{2} \mathrm{O}_{3}$ layer exhibits cracks, probably because there is not enough $\mathrm{Cr}$ to form a continuous and stable protecting scale, which explains the higher oxidation rate of this alloy compared to $\mathrm{W}-10 \mathrm{Cr}-0.5 \mathrm{Y}$. Taking into account the high oxidation rate of the $\mathrm{W}-10 \mathrm{Cr}-0.3 \mathrm{Y}$ alloy (Fig. 7 and 9), it is evident that the $\mathrm{Y}_{2} \mathrm{~W}_{3} \mathrm{O}_{12}$ phase plays an important role in the passivation effect of $\mathrm{W}-\mathrm{Cr}-\mathrm{Y}$ alloys. It seems that the $\mathrm{Y}_{2} \mathrm{~W}_{3} \mathrm{O}_{12}$ particles reinforce the protecting effect of the $\mathrm{Cr}_{2} \mathrm{O}_{3}$ scale.

Taking into account the much lower amount of this phase after isothermal oxidation at $800^{\circ} \mathrm{C}$, and the fact that $\mathrm{WO}_{3}(\mathrm{~s})$ starts to sublimate at $750^{\circ} \mathrm{C}$ [25], it is plausible to assume that $\mathrm{Y}_{2} \mathrm{~W}_{3} \mathrm{O}_{12}$ forms by the reaction of $\mathrm{Y} 2 \mathrm{O} 3$ with $\mathrm{WO}_{3}(\mathrm{~g})$, as proposed also in [24].

\subsection{Thermal shock tests}

The as HIPed and the HIP+HTed W-10Cr-0.5Y alloys were exposed to 1000 heat pulses of $0.19 \mathrm{GW} / \mathrm{m}^{2}$ for $1 \mathrm{~ms}$ at $400^{\circ} \mathrm{C}$ and subsequently to similar 1000 heat pulses of $0.38 \mathrm{GW} / \mathrm{m}^{2}$. The latter pulses simulate the conditions expected during ELMs in the divertor, while the load at the blanket first wall during ELMs will be significantly lower. Nevertheless, in a DEMO-like device massive gas injection will be used to mitigate or avoid disruptions; this gas injection will produce photon flashes, which result in very similar loads at the first wall to those applied here in a single pulse. Thus, this test simulates the load at the first wall after 1000 mitigated disruptions.

Taking into account the absorbed load of $0.38 \mathrm{GW} / \mathrm{m}^{2}$, the pulse duration of $1 \mathrm{~ms}$ and the thermo-physical properties of the materials at the base temperature of $400{ }^{\circ} \mathrm{C}$, a temperature increase of about $1000 \mathrm{~K}$ is expected. The fast increase in surface temperature during thermal shock loading and the formation of a steep temperature gradient causes high compressive stresses in the small heat affected zone. At temperatures above the DBTT the ductility of the material should be able to compensate the plastic deformation and the induced stresses resulting in an increased surface roughness. In contrast, at temperatures below the DBTT the risk of brittle crack formation increases due to fast cooling across the DBTT. In the present case, after the pulses of $0.19 \mathrm{GW} / \mathrm{m}^{2}$ no damage was detected at the surface of the samples. After 1000 pulses of $0.38 \mathrm{GW} / \mathrm{m}^{2}$ the surface of the as-HIPed material was chipped whereas the sample after HT exhibited just a crack network with no chipping, as can be observed in Fig. 12. The surface roughness of the HIP+HTed material was reduced with respect to pure $\mathrm{W}$ grade reference material IGP $\mathrm{W}$ [26] under the same conditions from $0.52 \mu \mathrm{m}$ to $0.26 \mu \mathrm{m}$. The cracks in the alloy after HT are clearly narrower than those of the as-HIPed material. Compared to the pure W reference material, the HTed W$10 \mathrm{Cr}-0.5 \mathrm{Y}$ alloy exhibits a larger crack density, but the crack length and width is significantly lower for the alloy than for pure $\mathrm{W}$. 


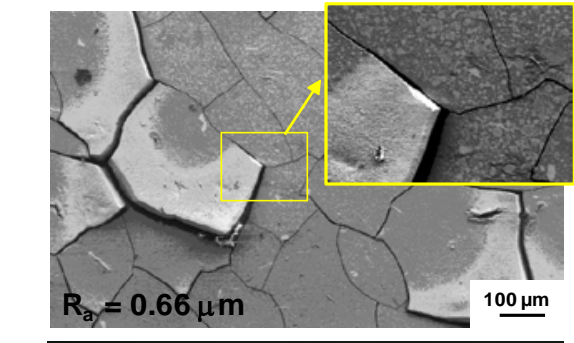

(a)

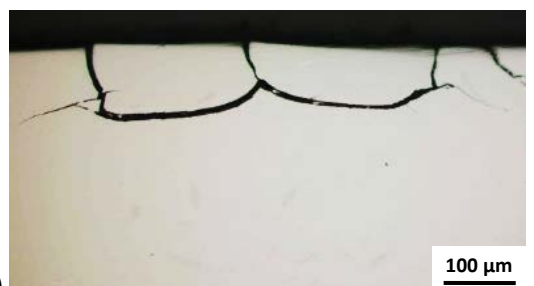

(b)
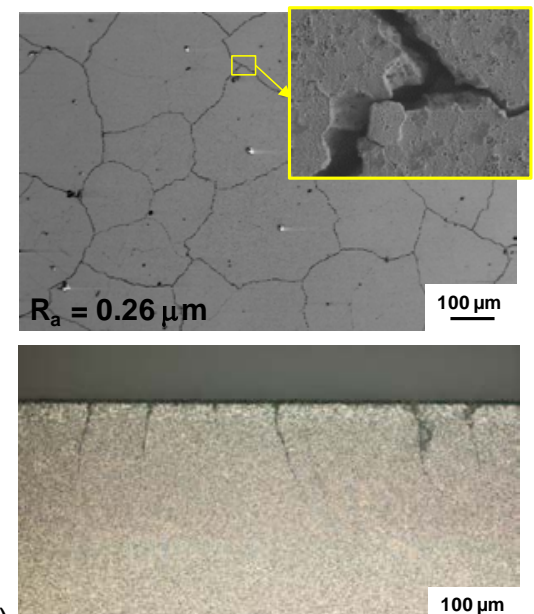

$\underline{100 \mu \mathrm{m}}$

(c)

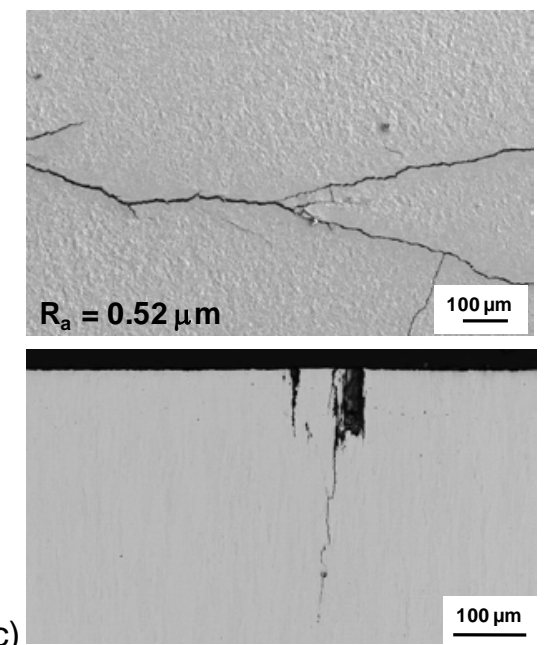

Figure 12: Surface and cross section after loading at JUDITH-1 with 1000 ELM-like pulses of $0.38 \mathrm{GW} / \mathrm{m}^{2}$ for $1 \mathrm{~ms}$ on (a) asHIPed W-10Cr-0.5Y, (b) HIP+HTed W-10Cr-0.5Yand (c) pure tungsten reference material IGP W [26]

The $\mathrm{W}-10 \mathrm{Cr}-0.5 \mathrm{Y}$ alloy presents an improved performance to thermal shock loading compared to previously tested alloys of the system $\mathrm{W}-\mathrm{Cr}-\mathrm{Ti}$ [7], which is likely due to the reinforcement attained in both strength and toughness at high temperatures. The very fine microstructure and the presence of $\mathrm{Y}$-rich oxide nanoparticles together with the slightly higher thermal conductivity might be responsible for this improvement. The HT clearly contributes to improve the thermal shock resistance since only a single phase is present in the material, which leads to stress relief.

\section{Conclusions}

Fully dense self-passivating alloys of compositions W-8Cr-0.5Y, W-10Cr-0.3Y, W-10Cr-0.5Y and W-10Cr$1 Y$ (in wt.\%) were produced by MA and HIP. Alloys containing 0.3 and $0.5 \% \mathrm{Y}$ are nanocrystalline and exhibit a $\mathrm{Y}_{2} \mathrm{O}_{3}$ nanoparticle dispersion mainly at the $\mathrm{GB}$, inhibiting grain growth and contributing to increase the high temperature strength compared to previous alloys of the W-Cr-Ti system. For the alloy containing $1 \% \mathrm{Y}$ there is not enough oxygen to form $\mathrm{Y}_{2} \mathrm{O}_{3}$, resulting in coarsening of the $\mathrm{Y}$-O-rich nanoparticles and thus, to a less efficient inhibition of grain growth.

The thermal conductivity of the alloys is about 2.5 times higher than Inconel 718 at $600-900^{\circ}$, resulting in a temperature increase $<100 \mathrm{~K}$ for the conditions expected at the PFMs of the DEMO blanket.

The $\mathrm{W}-10 \mathrm{Cr}-1 \mathrm{Y}$ alloy exhibit the lowest oxidation rates of all investigated alloys both under isothermal and accident-like conditions. The $\mathrm{Y}_{2} \mathrm{~W}_{3} \mathrm{O}_{12}$ phase formed at the surface ad inside the $\mathrm{Cr}_{2} \mathrm{O}_{3}$ scales seems to contribute substantially to the oxidation reduction of these alloys by improving and stabilizing the selfpassivating effect of the $\mathrm{Cr}_{2} \mathrm{O}_{3}$ scale.

A final $\mathrm{HT}$ at $1550^{\circ} \mathrm{C}$ improves slightly the behavior of the $\mathrm{W}-10 \mathrm{Cr}-0.5 \mathrm{Y}$ alloy under oxidation and significantly under thermal shock conditions, where this alloy exhibits comparable or better performance than a pure $\mathrm{W}$ reference material. 


\section{Acknowledgments}

This work has been carried out within the framework of the EUROfusion Consortium and has received funding from the Euratom research and training programme 2014-2018 under grant agreement No 633053 and from the Basque Government (ELKARTEK FRONTIERS KK-2015/00101). The views and opinions expressed herein do not necessarily reflect those of the European Commission.

\section{References}

1. D. Stork, P. Agostini, J.L. Boutard, D. Buckthorpe, E. Diegelee, S.L. Dudarev et al. Materials R\&D for a timely DEMO: Key findings and recommendations of the EU Roadmap Materials Assessment Group. Fusion Eng Des 2014; 89:1586-94. http://dx.doi.org/10.1016/j.fusengdes.2013.11.007.

2. D. Maisonnier, P.I. Cook, R.A. Sardain, L.D. Pace, R. Forrest, L. Giancarli , S. Hermsmeyer , P. Norajitra, N. Taylor, D. Ward, Final Report of the European Fusion Power Plant Conceptual Study (PPCS), EFDA (05)-27/4.10 (2005)

3. F. Koch, S. Koeppl, H. Bolt. Self passivating W-based alloys as plasma-facing material. J Nuclear Mater 2009:386 - 388, 572-4. http://dx.doi:10.1016/j.jnucmat.2008.12.179.

4. F. Koch, J. Brinkmann, S. Lindig, S. Lindig, T.P. Mishra, Ch. Linsmeier. Oxidation behaviour of silicon-free tungsten alloys for use as the first wall material. Phys Scr 2011;T145:14019-23. http://dx.doi:10.1088/0031-8949/2011/T145/014019.

5. P. Lopez-Ruiz, N. Ordás, I. Iturriza, M. Walter, E. Gaganidze, S. Lindig, F. Koch, C. Garcia-Rosales. Powder metallurgical processing of self-passivating tungsten alloys for fusion first wall application. J Nucl Mater 2013:442:S219-24. http://dx.doi.org/10.1016/j.jnucmat.2012.12.018.

6. C. García-Rosales, P. López-Ruiz, S. Alvarez-Martín, A. Calvo, N. Ordás, F. Koch, J. Brinkmann. Oxidation behaviour of bulk W-Cr-Ti alloys prepared by mechanical alloying and HIPing. Fusion Eng Des 2014;89:1611-6. http://dx.doi.org/10.1016/j.fusengdes.2014.04.057

7. A. Calvo, C. García-Rosales, F. Koch, N. Ordás, I. Iturriza, H. Greuner, G. Pintsuk, C. Sarbu. Manufacturing and testing of self-passivating tungsten alloys of different composition. Nucl Mater Energy 2016;9:422-9. http://dx.doi.org/10.1016/j.nme.2016.06.002

8. T. Wegener, F. Klein, A. Litnovsky, M. Rasinski, J. Brinkmann, F. Koch, Ch. Linsmeier. Development of yttrium-containing self-passivating tungsten alloys for future fusion power plants. Nucl Mater Energy 2016;9:394-8. http://dx.doi.org/10.1016/j.nme.2016.07.011

9. M. Zhao, Z. Zhou, Q. Ding, M. Zhong, K. Arshad. Effect of rare earth elements on the consolidation behavior and microstructure of tungsten alloys. Int J Refract Met Hard Mater 2015;48:19-23. http://dx.doi.org/10.1016/j.jirmhm.2014.07.014

10. L. Veleva, R. Schaeublin, M. Battabyal, T. Plociski, N. Baluc. Investigation of microstructure and mechanical properties of $\mathrm{W}-\mathrm{Y}$ and $\mathrm{W}-\mathrm{Y} 2 \mathrm{O} 3$ materials fabricated by powder metallurgy method. Int J Refract Met Hard Mater 2015;50: 210-6. http://dx.doi.org/10.1016/j.jirmhm.2015.01.011.

11. J. Linke, T. Hirai, M. Roedig, L. Singheiser. Performance of plasma-facing materials under intense thermal loads in tokamaks and stellarators. Fus Sci Technol 2004;46:142-51. http://dx.dx.doi.org/10.13182/FST04-A550. 
12. W-Cr phase diagram. Bulletin of Alloy Phase Diagrams Vol. 5 No. 3; 1984.

13. R. Duwe, W. Kühnlein, H. Münstermann. The new electron beam facility for material testing in hot cells - design and preliminary experience. Fusion Technol 1994;355-358.

14. A. Calvo, C. García-Rosales, N. Ordás, I. Iturriza, K. Schlueter, F. Koch, G. Pintsuk, E. Tejado, J.Y. Pastor, Self-passivating W-Cr-Y alloys: characterization and testing, Fusion Eng Des 2017, in press. http://dx.doi.org/10.1016/j.fusengdes.2017.03.001.

15. T. Palacios, J.Y. Pastor. Influence of the notch root radius on the fracture toughness of brittle metals: Nanostructure tungsten alloy, a case study. Int J Refract Met Hard Mater 2015;52:44-9.

16. G. V. Guinea, J.Y. Pastor, J. Planas, M. Elices. Stress Intensity factor, compliance and CMOD for a General Three-Point-Bend Beam. Int J Fract 1998;89:103-16.

17. M.-N. Avettand-Fènoël, R. Taillard, J. Dhers, J. Foct. Effect of ball milling parameters on the microstructure of W-Y powders and sintered samples. Int J Refract Met H 2003;21:205-13. http://dx.doi:10.1016/S0263-4368(03)00034-9.

18. Y. Muramatsu, S. Wanikawa, M. Ohtaguchi, H. Okada, F. Abe. Gas Contamination due to Milling Atmospheres of Mechanical Alloying and Its Effect on Impact strength. Mater Trans 2005;46:681-6.

19. G. Wegmann, R. Gerling, F.P. Schimansky. Temperature induced porosity in hot isostatically pressed gamma titanium aluminide alloy powders. Acta Mater 2003;51:741-52. http://dx.doi:10.1016/S1359-6454(02)00465-2.

20. T. Palacios, A. Jiménez, A. Muñoz, M.A. Monge, C. Ballesteros, J.Y. Pastor. Mechanical characterisation of tungsten-1 wt.\% yttrium oxide as a function of temperature and atmosphere. $\mathrm{J}$ Nucl Mater 2014;454:455-61. http://dx.doi.org/10.1016/j.jnucmat.2014.09.012.

21. U.K. Vashi, R.W. Armstrong, G.E. Zima. Metall Trans 1970;1:1769-71.

22. F. Arbeiter, C. Bachmann, Y. Chen, M. Ilic, F. Schwab, B. Sieglin, R. Wenninger. Thermal-hydraulics of helium cooled First Wall channels and scopinginvestigations on performance improvement by application of ribsand mixing devices. Fusion Eng Des 2015;109-111:1123-9. http://dx.doi.org/10.1016/j.fusengdes.2016.01.008.

23. J. Reiser, J. Hoffmann, U. Jäntsch, M. Klimenkov, S. Bonk, C. Bonnekoh, M. Rieth, A. Hoffmann, T. Mrotzek. Ductilisation of tungsten (W): On the shift of the brittle-to-ductile transition (BDT) to lower temperatures through cold rolling. Int J Refract Met Hard Mater 2016;54:351-69. http://dx.doi.org/10.1016/j.ijrmhm.2015.09.001.

24. S. Telu, R. Mitra, S.K. Pabi. Effect of $\mathrm{Y}_{2} \mathrm{O}_{3}$ Addition on Oxidation Behavior of W-Cr Alloys. Metall Mater Trans A 2015. DOI: 10.1007/s11661-015-3166-z.

25. E. Lassner, W.D. Schubert. Tungsten: Properties, Chemistry, Technology of the Element, Alloys and Chemical Compounds. New York: Kluwer Academic; 1999.

26. M. Wirtz, J. Linke, T. Loewenhoff, G. Pintsuk, I. Uytdenhouwen. Thermal shock tests to qualify different tungsten grades as plasma facing material Phys Scr 2016;T167:14015. http://doi:10.1088/0031-8949/T167/1/014015. 